\title{
NOTE
}

\section{First report of coral diseases in the Republic of Maldives}

\author{
Simone Montano ${ }^{1,2, *}$, Giovanni Strona ${ }^{1,2}$, Davide Seveso ${ }^{1,2}$, Paolo Galli ${ }^{1,2}$ \\ ${ }^{1}$ Department of Biotechnologies and Biosciences, University of Milan-Bicocca, Piazza della Scienza 2, 20126, Milan, Italy \\ ${ }^{2}$ MaRHE Center (Marine Research and High Education Center), Magoodhoo Island, Faafu Atoll, Republic of Maldives
}

\begin{abstract}
Little is known about coral diseases in the Indian Ocean region, especially in the Republic of Maldives. This study aimed at documenting the presence of coral diseases in the archipelago of the Maldives. Surveys for lesions in scleractinians conducted at 8 sites around Magoodhoo Island (Faafu Atoll) in October and November 2010 led to the identification of 5 coral diseases and 1 anomalous pigmentation response affecting 8 hard coral genera. White syndrome, skeleton-eroding band disease, black band disease, and Porites dark discoloration response were the most commonly observed conditions. In contrast with several reports of other reef systems, the overall observed prevalence of coral diseases was rather low $(<2 \%)$, with individual prevalence ranging from $0.7 \%$ for skeleton-eroding band to $0.18 \%$ for Porites dark discoloration response. These data represent the first report of coral diseases for the Republic of Maldives.
\end{abstract}

KEY WORDS: Maldivian Archipelago · Coral reefs · White syndrome - Skeleton-eroding band . Black band disease $\cdot$ Porites dark discoloration response

Resale or republication not permitted without written consent of the publisher

\section{INTRODUCTION}

Coral disease epizootics have become a major threat to reef ecosystems globally, and an increasing number of newly emerging syndromes has been reported over the past $20 \mathrm{yr}$ (Harvell et al. 1999, Raymundo et al. 2005, Sokolow 2009). Because climate change is predicted to amplify host susceptibility, host range, pathogen survival, and disease transmission (Ritchie et al. 2001, Myers \& Raymundo 2009), outbreaks are expected to increase worldwide in the future (Willis et al. 2004, Bruno et al. 2007).

The coral reefs of the Maldivian Archipelago are among the most diverse in the Indian Ocean and are known to host more than 180 zooxanthellate coral species belonging to 51 genera (Pichon \& Benzoni 2007). The major reef structures occupy an area of about $21000 \mathrm{~km}^{2}, 21.1 \%$ of which can be categorized as marine productive reef habitats (Naseer \& Hutcher 2004).

Worldwide, researchers are growing alarmed about the potential negative effects of infectious diseases on reef communities (Bruno et al. 2007). Temporary shifts from acroporid- to agaricid-dominated reefs caused by disease-induced mortality have already occurred in Belize (Aronson et al. 2002), and outbreaks of coral diseases have caused a significant loss of coral cover in the Caribbean Sea and on the Great Barrier Reef (Willis et al. 2004, Weil et al. 2009).

The Maldivian Archipelago was heavily affected by a coral bleaching event in 1998, which led to coral mortality of up to $100 \%$ with varying effects depending on species and locality (Bianchi et al. 2003). The living coral cover ranged from 2 to $8 \%$ immediately after the mass mortality event and increased up to 12 
to $37 \%$ in the following $8 \mathrm{yr}$ (Lasagna 2008). The mass mortality event associated with coral bleaching also induced a qualitative change in the coral communities, with a shift from Acropora-dominated reefs to Porites-dominated reefs (Goreau et al. 2000).

The ecological impact of bleaching on coral communities, and particularly its ability to increase coral susceptibility to infectious disease, is well documented (McClanahan et al. 2009). However, no information is available about the presence of coral diseases in the Maldives. Here, we attempted to fill this gap by reporting the results of a survey conducted to investigate the occurrence and prevalence of diseases affecting reef-building corals in an island of the Republic of Maldives.

\section{MATERIALS AND METHODS}

Underwater surveys were conducted during October and November 2010 in order to investigate the presence and prevalence of infectious diseases affecting scleractinian corals in the waters around the inhabited island of Magoodhoo, Faafu Atoll, Republic of Maldives ( $3^{\circ} 04^{\prime} \mathrm{N}, 72^{\circ} 57^{\prime} \mathrm{E}$; Fig. 1). The island measures $900 \times 450 \mathrm{~m}$ and is located on the south-east part of the atoll rim, about $140 \mathrm{~km}$ south of the capital Malè. Magoodhoo reef is approximately $2.9 \mathrm{~km}$ long and $1.55 \mathrm{~km}$ wide and exhibits the features of a typical low-energy reef with a luxuriant growth of coral and gentle slopes to all sides. Sites were selected haphazardly from those that were accessible.

During the sampling period, which fell within the wet season (mid-May to November), the local monthly mean sea surface temperature was $29.1 \pm$ $0.12^{\circ} \mathrm{C}(\mathrm{SD})$, and temperature variation among seasons did not exceed $1^{\circ} \mathrm{C}$ (http://disc.sci.gsfc.nasa. gov/techlab/giovanni). Analyses were conducted by snorkeling at shallow sites ( $\mathrm{n}=4,0-5 \mathrm{~m}$ ) and by scuba diving at deep sites $(\mathrm{n}=4,10-20 \mathrm{~m}$; Fig. 1c). For each site, we performed an exploratory qualitative analysis aimed at compiling a complete list of the hard coral diseases occurring in the area. Additionally, quantitative information about coral disease prevalence at each site was obtained by establishing 3 randomly placed $25 \times 1$ m belt transects (total $=24$ transects) spaced 10 to $20 \mathrm{~m}$ apart. Colonies on the belt margin were counted only when $50 \%$ or more of the colony lay within the belt. The selected transect size was chosen as the most suitable in relation to field logistics and the size of the surveyed area.

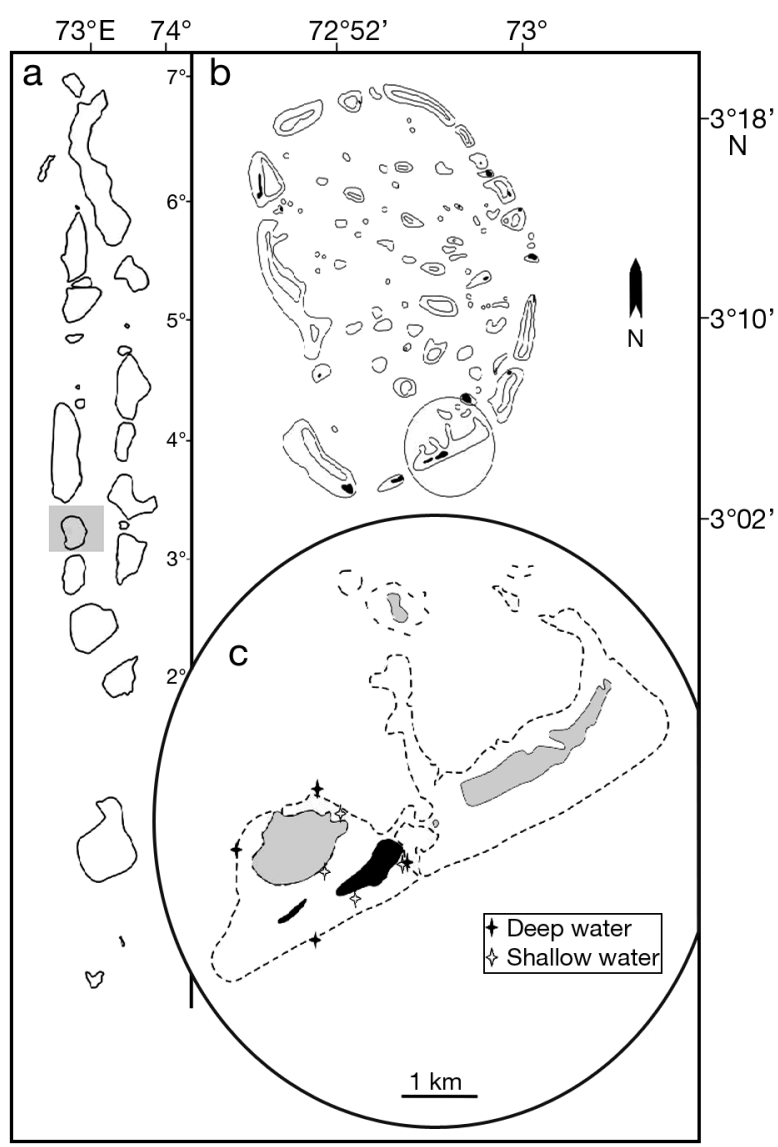

Fig. 1. Study area. (a) Republic of Maldives; (b) Faafu Atoll; (c) Magoodhoo Island, showing the 8 sampling sites

In both the qualitative and quantitative analyses, all corals were identified in situ to the genus level (according to Veron 2000). Diseases were identified in situ as well (according to Rosenberg \& Loya 2004). Small samples of both healthy and infected coral tissue were collected for further laboratory identification. Visible symptoms of disease or stress not ascribable to those reported from available literature were described and photographed when encountered. Microphotographs $(32 \times)$ of infected colonies were obtained using a StemiDIV4 stereomicroscope paired with a Canon G11 camera.

All diseased colonies within each belt transect were noted, and the number of diseased and healthy colonies was counted in order to compute disease prevalence, which was calculated as the number of infected colonies divided by the total number of colonies. Taxon-specific prevalence was calculated as the number of cases of a specific disease or syndrome divided by the number of appropriate hosts encountered. The average total disease prevalence for each site was calculated by averaging the prevalence in all belt transects. 


\section{RESULTS}

\section{Occurrence and prevalence of observed diseases}

Our survey of the reefs of Magoodhoo Island revealed the presence of 5 syndromes affecting different genera of reef-building corals, namely black band disease, ulcerative white spot disease, white syndrome, skeleton-eroding band, and brown band disease. Additionally, we observed a dark discoloration response on Porites spp. loosely similar to that typical of dark spot disease, which we hereafter refer to as Porites dark discoloration response, in order to distinguish it from any common disease and tissue pigmentation response known for this genus (Raymundo et al. 2005).

In total, we counted 2761 colonies belonging to 19 genera. Among them, disease-induced lesions were observed on 64 colonies (belonging to 8 genera), 50 of which (belonging to 6 genera) were found within transects. Thus, the resulting overall prevalence of coral diseases on the reef was lower than $2 \%$. Individual prevalence of each investigated

Table 1. Occurrence of coral diseases across all coral genera found at 8 sites on Magoodhoo Island, Faafu Atoll, Republic of Maldives. n: number of colonies; BBD: black band disease; SEB: skeleton-eroding band; WS: white syndrome; PDDr: Porites dark discoloration response; BrBD: brown band disease; UWS: ulcerative white spot; ?: to be confirmed

( ): not found within transects

\begin{tabular}{|c|c|c|c|c|c|c|c|}
\hline Genus & $\mathrm{n}$ & BBD & SEB & WS & PDDr & BrBD & UWS \\
\hline Acropora & 1162 & 1 & 14 & 15 & & (2) & (3)? \\
\hline Cyphastrea & 10 & & & & & & \\
\hline Favia & 14 & & & & & & \\
\hline Favites & 28 & & & & & & \\
\hline Fungia & 45 & & & & & & \\
\hline Echinopora & 10 & & & (1) & & & \\
\hline Gardineroseris & 6 & & & & & & \\
\hline Goniastrea & 22 & (2) & (1) & & & & \\
\hline Goniopora & 7 & 2 & & & & & \\
\hline Hydnophora & 7 & & & & & & \\
\hline Isopora & 122 & & & & & & \\
\hline Leptastrea & 23 & & & & & & \\
\hline Leptoria & 19 & & & & & & \\
\hline Montipora & 56 & & & & & & \\
\hline Pavona & 742 & 2 & & & & & \\
\hline Platygyra & 15 & & & & & & \\
\hline Pocillopora & 138 & & 4 & & & & \\
\hline Porites & 252 & & & & 6 & & (3) \\
\hline Psammocora & 83 & 6 & & $(2)$ & & & \\
\hline Total & 2761 & 11 & 18 & 15 & 6 & - & - \\
\hline
\end{tabular}

Table 2. Total prevalence and depth distribution of observed coral diseases. Lower (LL) and upper (UL) 95\% bootstrap confidence limits

\begin{tabular}{|llrrrr|}
\hline \multirow{2}{*}{$\begin{array}{l}\text { Disease } \\
\text { Affected genus }\end{array}$} & \multicolumn{3}{c}{ Prevalence } & \multicolumn{2}{c|}{ Station } \\
& Mean & LL & UL & Shallow & Deep \\
\hline Black band disease & 0.34 & 0.13 & 0.74 & & \\
Psammocora & 4.4 & 0.83 & 7.73 & Yes & No \\
Goniopora & 5 & 0 & 18.75 & Yes & No \\
Pavona & 0.5 & 0 & 1.38 & Yes & No \\
Acropora & 0.1 & 0 & 0.27 & No & Yes \\
Skeleton-eroding band & 0.7 & 0.41 & 0.99 & & \\
Acropora & 1.3 & 0.78 & 2.63 & Yes & Yes \\
Pocillopora & 3.6 & 1.19 & 11.42 & Yes & Yes \\
Porites dark & 0.18 & 0.07 & 0.31 & & \\
discoloration response & & & & & \\
$\quad \begin{array}{l}\text { Porites } \\
\text { White syndrome }\end{array}$ & 2.9 & 1.01 & 6.07 & Yes & No \\
Acropora & 0.64 & 0.41 & 0.92 & & \\
& 1.4 & 0.78 & 2.41 & Yes & Yes \\
\hline
\end{tabular}

coral disease was lower than $1 \%$, ranging from $0.7 \%$ (skeleton-eroding band) to $0.18 \%$ (Porites dark discoloration response). Although qualitative surveys revealed the presence of brown band disease and ulcerative white spot, the 2 diseases were not found within transects. For the other diseases (black band disease, skeleton-eroding band, and white syndrome) as well as for Porites dark discoloration response, we report the number of occurrences across all coral genera that we found (Table 1). All diseases observed were found at the shallow sites, while at the deeper sites, Porites dark discoloration response was not found. A preliminary assessment of disease prevalence among affected coral genera is reported in Table 2 .

\section{Description of observed diseases}

We found evidence of coral disease in 5 scleractinian families: Acroporidae, Poritidae, Faviidae, Pocilloporidae, and Agariciidae. More than half (54.7\%) of the diseased colonies belonged to the Acroporidae, which was thus the most affected family. The other diseased colonies belonged to the Poritidae $(17.3 \%)$, Siderasteridae $(12.5 \%)$, Faviidae $(6.2 \%)$, Pocilloporidae (6.2\%), and Agariicidae (3.1\%). Among the affected genera, Acropora hosted the highest number of coral diseases $(\mathrm{n}=5)$, while the remaining genera were affected by a maximum of 2 diseases.

Black band disease (Fig. 2a), which is caused by a mat of microbes dominated by the cyanobacterium 
Phormidium corallitycum (Rützler \& Santavy 1983; Fig. 2b), showed the largest host range, affecting 5 different coral genera, particularly Psammocora and Goniopora. Ulcerative white spot disease (Fig. 2c), which was found mainly on Porites, was characterized by discrete, bleached round foci of 3 to $5 \mathrm{~mm}$ in

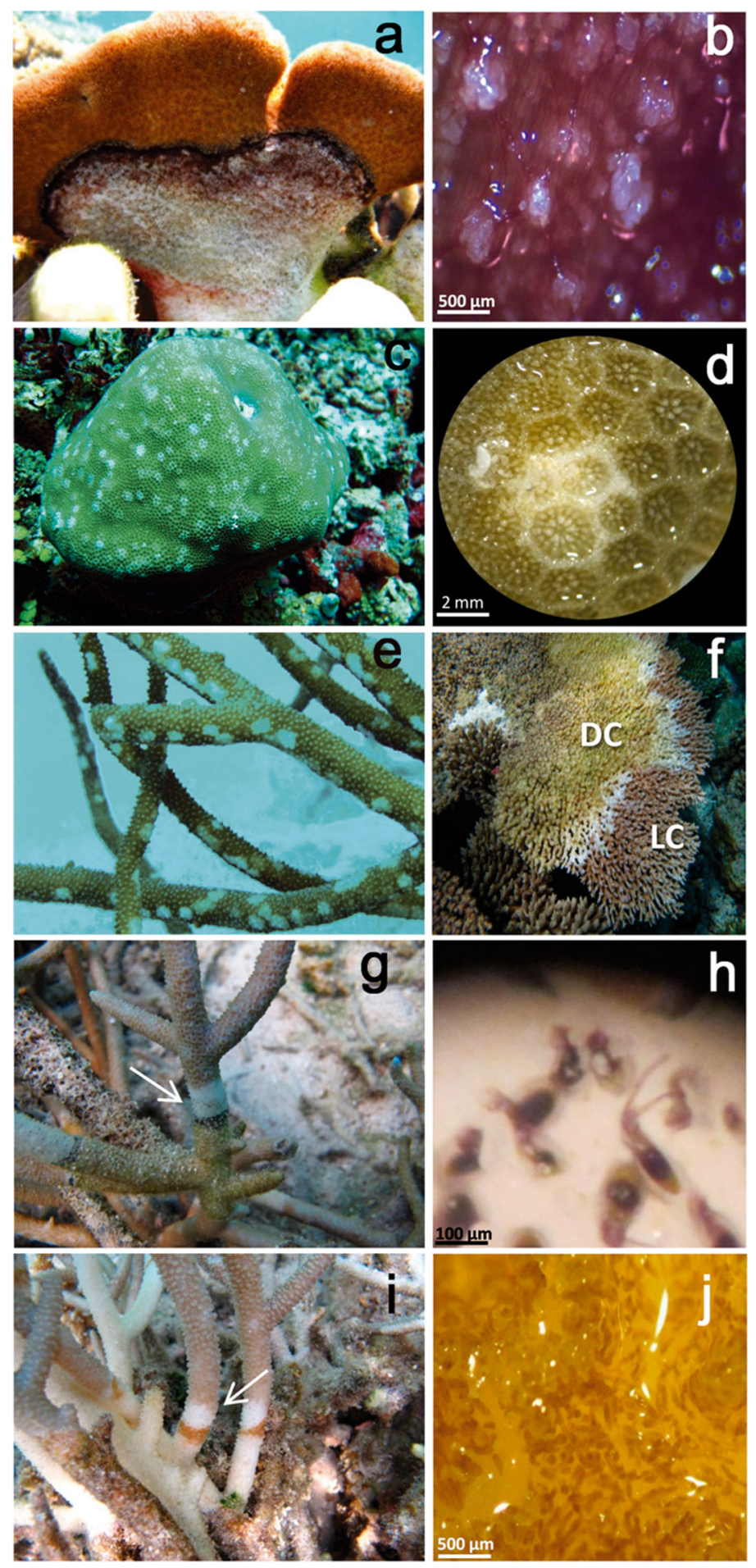

diameter, consistent with the description given by Raymundo et al. (2003; Fig. 2d). Lesions that resembled ulcerative white spot were also observed on some colonies of Acropora spp. (Fig. 2e). These lesions were characterized by discrete, multifocal round foci that revealed an underlying intact skeleton. These injured areas were mainly located in the basal portion of the colonies. Similarly to the description given by Work \& Aeby (2006), the lesions due to white syndrome (Fig. 2f) consisted of large, diffuse bands of tissue loss that revealed a bare, white, intact skeleton. The lesions were mildly to severely extended, and the tissue loss involved the coenosarc and the polyps of the colonies belonging to the genus Acropora. We closely examined all colonies affected by white syndrome and ulcerative white spot, and we found no evidence suggesting an involvement of coral predators in tissue death.

Skeletal-eroding band (Fig. 2g), which is associated with the ciliate Halofolliculina corallasia (Antonius 1999, Willis et al. 2004; Fig. 2h), was found on the genera Acropora, Pocillopora, and Goniastrea, while brown band disease (Fig. 2i), which is caused by a mobile ciliate (Fig. 2j) such as the recently described Porpostoma guamense (Lobban et al. 2011), was found only on branching Acropora spp. Members of the genus Porites that were affected by the dark discoloration response were characterized by small to large areas of brown discoloration with indistinct undulating borders (Fig. 3); in addition, diseased colonies showed lesions both focally and diffusely distributed at peripheral areas.

Fig. 2. Photographs illustrating the coral diseases found in Magoodhoo reef. (a) Black band disease on Psammocora digitata colony; (b) close up of the mat forming the black band; (c) ulcerative white spot on a massive Porites colony; (d) areas of white tissue discoloration with discrete margins; (e) signs similar to ulcerative white spot on an Acropora spp. colony; (f) Acropora plate coral with white syndrome; the white band is the lesion area, with live coral (LC) on the right and dead coral ( $\mathrm{DC}$; colonized by filamentous algae) on the left; (g) skeleton-eroding band (arrow) on a branching Acropora muricata colony; (h) Halofolliculina corallasia: note the large peristomial wings coming out of the lorica; (i) brown band disease (arrow) on a branching A. muricata colony; (j) details of ciliate clustering constituting the band. Photos by S. Montano 


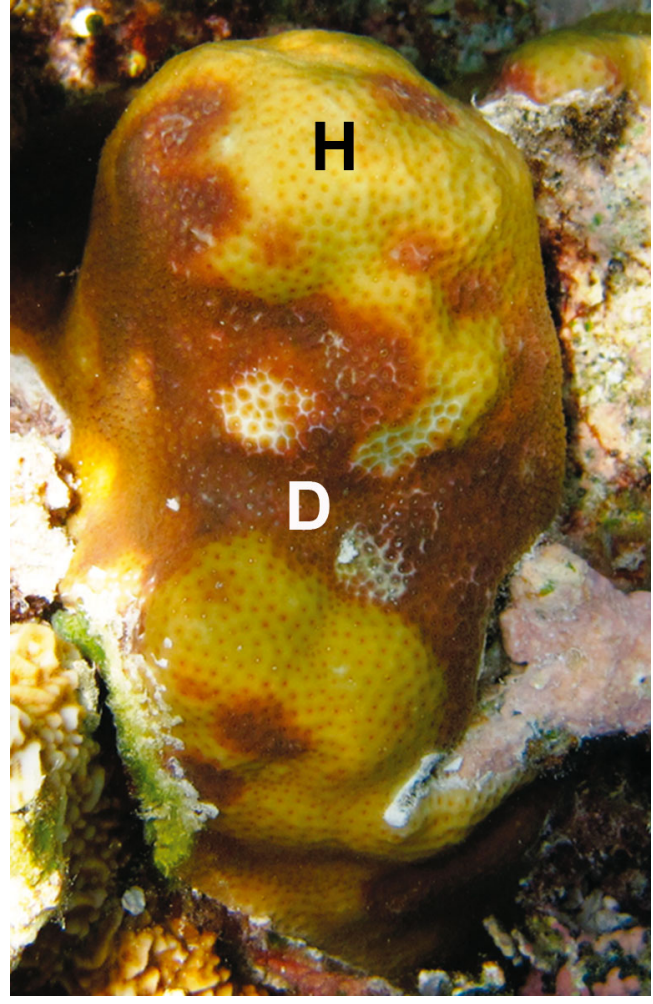

Fig. 3. Porites dark discoloration response, showing the regular color of the healthy $(\mathrm{H})$ part of the colony and the anomalous pigmentation response found on Magoodhoo Island. This response consists of an abnormal dark purple discoloration (D) of the coral tissue. Photo by S. Montano

\section{DISCUSSION}

This study provides baseline information on the status of diseases affecting scleractinian corals in a previously unsampled region. Our surveys documented the presence of 5 different coral diseases and 1 anomalous pigmentation response in the reefs of Magoodhoo Island. All pathologies observed in this study have been previously reported from the Indo-Pacific region. Nonetheless, the data presented here constitute the first records of coral diseases in the Maldivian Archipelago.

All observed coral diseases were present apparently with low prevalence, which is in contrast with several other studies on reef systems (Myers \& Raymundo 2009, Weil et al. 2012). The most commonly observed diseases were skeleton-eroding band, black band disease (consistent with the assumptions of their circumglobal distribution; Cróquer et al. 2006, Myers \& Raymundo 2009), and white syndrome. However, white syndrome showed a much lower prevalence than that already observed in similar ecosystems (e.g. Willis et al. 2004, Hobbs \& Frish
2010 for the Indo-Pacific; Sutherland et al. 2004 for the Caribbean).

Our surveys also revealed the presence of 1 anomalous pigmentation response, which we termed Porites dark discoloration response and which was relatively widespread in the study area. We observed no skeleton or tissue damage caused by scars, tumors, or other known lesions associated with the condition. This suggests that the response may be triggered by unidentified chemical and/or microbial agents, or may be interpreted as a hypermelanization response to a pathogen (Petes et al. 2003). Further investigation would improve our knowledge of this response or disease. We recorded a few cases of brown band disease and ulcerative white spot, which extend the documented geographic range for these 2 diseases (Weil et al. 2012). In particular, we extend the range of brown band disease westward from the Philippines and the Great Barrier Reef (Raymundo et al. 2003, Willis et al. 2004). Interestingly, we noticed signs of infections similar to those due to ulcerative white spot on several Acropora colonies. Although still to be confirmed by more detailed analyses, this finding may suggest a possible increase in host range for the disease, which so far has been reported mainly from Porites spp. (Raymundo et al. 2003, Kaczmarsky 2006). Among coral genera, Acropora hosted the highest number of coral diseases. This supports the hypothesis that fast-growing corals might have a weaker disease resistance than slowgrowing corals (Willis et al. 2004, Palmer et al. 2008, 2010, Mydlarz et al. 2010). Overall, less than half of the sampled genera were affected by at least 1 coral disease. This could suggest a low spread of hostspecific coral diseases (Raymundo et al. 2005).

Despite the fact that the Maldives, and hence our study area, were affected by a mass coral bleaching event in 1998 (Longo et al. 2000, Zahir 2000), the currently available data do not allow us to confirm a relationship between the past thermal stress and the current diffusion of coral diseases. However, the expected future increase in sea surface temperatures (Kleypas et al. 1999) could lead not only to new bleaching events but could also promote the spread of coral pathogens by increasing their growth rate and virulence (Ben-Haim et al. 2003) and by reducing the immune response in coral hosts (Alker et al. 2001, Mydlarz et al. 2009, Palmer et al. 2011). Considering the current state of regression of many reefs in the Maldives (Lasagna et al. 2010), a better understanding of the actual and potential impact of infectious diseases on coral ecosystem dynamics is fundamental to conservation planning. 
Although we cannot rule out the possibility that our results may be affected by sample size, number of replicates, and local variation, and that they may not be representative of large-scale patterns valid for the whole Magoodhoo reef, we hope that our preliminary study will stimulate the interest of coral pathologists and promote future in-depth investigations focusing on coral diseases in Maldivian reefs.

Acknowledgements. We thank S. Masier for field support and 2 anonymous reviewers, whose comments greatly improved this manuscript.

\section{LITERATURE CITED}

Alker AP, Smith GW, Kim K (2001) Characterization of Aspergillus sydowii (Thom et Church), a fungal pathogen of Caribbean sea fan corals. Hydrobiologia 460:105-111

> Antonius A (1999) Halofolliculina corallasia, a new coralkiller ciliate on Indo-Pacific reefs. Coral Reefs 18:300

> Aronson RB, Macintyre IG, Precht WF, Murdoch TJT, Wapnick CM (2002) The expanding scale of species turnover events on coral reefs in Belize. Ecol Monogr 72:233-249

> Ben-Haim Y, Zicherman-Keren M, Rosenberg E (2003) Temperature-regulated bleaching and lysis of the coral Pocillopora damicornis by the novel pathogen Vibrio coralliilyticus. Appl Environ Microbiol 69:4236-4242

Bianchi CN, Pichon M, Morri C, Colantoni P, Benzoni F, Baldelli G, Sandrini M (2003) Le suivi du blanchissement des coraux aux Maldives: leçons à tirer et nouvelles hypothèses. Oceanis 29:325-354

- Bruno JF, Selig ER, Casey KS, Page CA and others (2007) Thermal stress and coral cover as drivers of coral disease outbreak. PLoS Biol 5:e124

Cróquer A, Bastidas C, Lipscomb D (2006) Folliculinid ciliates: a new threat to Caribbean corals? Dis Aquat Org 69: 75-78

Goreau T, McClanahan T, Hayes R, Strong A (2000) Conservation of coral reefs after the 1998 global bleaching event. Conserv Biol 14:5-15

Harvell CD, Kim K, Burkholder JM, Colwell RR and others (1999) Emerging marine diseases: climate links and anthropogenic factors. Science 285:1505-1510

Hobbs JPA, Frish AJ (2010) Coral disease in the Indian Ocean: taxonomic susceptibility, spatial distribution and role of host density on the prevalence of white syndrome. Dis Aquat Org 89:1-8

Kaczmarsky LT (2006) Coral disease dynamics in the central Philippines. Dis Aquat Org 69:9-21

Kleypas JA, Buddemeier RW, Archer D, Gattuso JP, Langdon C, Opdyke BN (1999) Geochemical consequences of increased atmospheric carbon dioxide on coral reefs. Science 284:118-120

Lasagna R, Albertelli G, Giovannetti E, Grondona M, Milani A, Morri C, Bianchi CN (2008) Status of Maldivian reefs eight years after the 1998 coral mass mortality. Chem Ecol 24:67-72

Lasagna R, Albertelli G, Colantoni P, Morri C, Bianchi CN (2010) Ecological stages of Maldivian reefs after the coral mass mortality of 1998. Facies 56:1-11

Lobban CS, Raymundo LM, Montagnes DJS (2011) Porpo- stoma guamense n. sp., a philasterine scuticociliate associated with brown-band disease of corals. Eukaryot Microbiol 58:103-113

Longo C, De Mandato P, Piscitelli M, Corriero G (2000) Osservazioni preliminari sulla mortalità di madreporari erma tipici nell'Arcipelago delle Maldive. Biol Mar Medit 7:686-690

McClanahan TR, Weil E, Maina J (2009) Strong relationship between coral bleaching and growth anomalies in massive Porites. Glob Change Biol 15:1804-1816

Mydlarz LD, Couch CS, Weil E, Smith G, Harvell CD (2009) Immune defenses of healthy, bleached and diseased Montastrea faveolata during a natural bleaching event. Dis Aquat Org 87:67-78

> Mydlarz LD, McGinty SE, Harvell CD (2010) What are the physiological and immunological responses of coral to climate warming and disease? J Exp Biol 213:934-945

> Myers RL, Raymundo LJ (2009) Coral disease in Micronesian reefs: a link between disease prevalence and host abundance. Dis Aquat Org 87:97-104

Naseer A, Hutcher BG (2004) Inventory of the Maldives' coral reefs using morphometrics generated from Landsat ETM+ imagery. Coral Reefs 23:161-168

Palmer CV, Myldzard LD, Willis BL (2008) Evidence of an inflammatory-like response in non-normally pigmented tissue of two scleractinian corals. Proc R Soc Lond B Biol Sci 275:2687-2693

> Palmer CV, Bythell JC, Willis BL (2010) Levels of immunity parameters underpin bleaching and disease susceptibility of reef corals. FASEB J 24:1935-1946

> Palmer CV, McGinty SE, Cummings DJ, Smith SM, Bartels E, Myldzard LD (2011) Patterns of coral ecological immunology: variation in the responses of Caribbean corals to elevated temperature and a pathogen elicitor. J Exp Biol 214:4240-4249

Petes LE, Harvell CD, Peters EC, Webb MAH, Mullen KM (2003) Pathogens compromise reproduction and induce melanization in Caribbean sea fans. Mar Ecol Prog Ser 264:167-171

Pichon M, Benzoni F (2007) Taxonomic re-appraisal of zooxanthellate scleractinian corals in the Maldive Archipelago. Zootaxa 1441:21-33

> Raymundo LJH, Harvell CD, Reynolds TL (2003) Porites ulcerative white spot disease: description, prevalence, and host range of a new coral disease affecting IndoPacific reefs. Dis Aquat Org 56:95-104

- Raymundo LJ, Rosell KB, Reboton CT, Karczmarsky LT (2005) Coral diseases on Philippine reefs: genus Porites is a dominant host. Dis Aquat Org 64:181-191

> Ritchie K, Polson SW, Smith GW (2001) Microbial disease causation in marine invertebrates: problems, practices and future prospects. Hydrobiologia 460:131-139

Rosenberg E, Loya Y (eds) 2004 Coral health and disease. Springer-Verlag, Berlin

> Rützler K, Santavy D (1983) The black band disease of Atlantic reef corals. PSZN I: Mar Ecol 4:301-319

$>$ Sokolow S (2009) Effects of a changing climate on the dynamics of coral infectious disease: a review of the evidence. Dis Aquat Org 87:5-18

Sutherland KP, Porter JW, Torres C (2004) Disease and immunity in Caribbean and Indo-Pacific zooxanthellate corals. Mar Ecol Prog Ser 266:273-302

Veron JEN (ed) (2000) Corals of the world, Vol 1-3. Australian Institute of Marine Science, Townsville

Weil E, Cróquer A, Urreiztieta I (2009) Temporal variability 
and consequences of coral diseases and bleaching in La Parguera, Puerto Rico from 2003-2007. Caribb J Sci 45: 221-246

Weil E, Irikawa A, Casareto B, Suzuki Y (2012) Extended geographic distribution of several Indo-Pacific coral reef diseases. Dis Aquat Org 98:163-170

Willis BL, Page CA, Dindsdale EA (2004) Coral disease in the Great Barrier Reef. In: Rosenberg E, Loya Y (eds)

Editorial responsibility: Garriet Smith,

Aiken, South Carolina, USA
Coral health and disease. Springer-Verlag, Berlin, p 69-104

- Work TM, Aeby GS (2006) Systematically describing gross lesions in coral. Dis Aquat Org 70:155-160

Zahir H (2000) Status of the coral reefs of Maldives after the bleaching event in 1998. In: Souter D, Obura D, Lindèn $\mathrm{O}$ (eds) Coral reef degradation in the Indian Ocean. CORDIO, Stockholm, p 64-68

Submitted: December 5, 2011; Accepted: August 9, 2012 Proofs received from author(s): October 14, 2012 